\title{
Energy Savings Alternative for Oil and Gas Industry through Analytical Hierarchy Process
}

\author{
Agustinus HD. Purwanto \\ University of Mercubuana \\ agus.hariadi.dp@gmail.com
}

\author{
Cokorda Prapti Mahandari \\ Gunadarma University \\ coki@staff.gunadarma.ac.id
}

\author{
Anggananda B. Raja Maruahal \\ Gunadarma University \\ angganan@gmail.com
}

\begin{abstract}
This work presents an analytical hierarchy process (AHP) to rank alternatives on energy saving opportunities as provided by an energy audit report undertaken on an onshore and offshore oil and gas operation in Java Sea. The AHP criteria applied include energy saving assessment, financial capability, environment sustainability and human resources in which each criterion constitutes of 3 (three) sub-criteria. Firstly, the energy saving assessment is comprised of energy consumption decline on certain period, energy elasticity decline for a certain period and energy intensity decline percentage. Secondly, the financial capability constitutes of minimum cost, payback period and optimize timetable. Thirdly, environment sustainability is grouped into minimize environmental pollution, renewable resources and fuel reserve. Finally, the human resources is developed by management, technical skill and enforcement. Identified saving options' alternativesare comprised ofenergy performance assessment and regular monitoring, implementation of ISO 50001, power plant set up, waste heat recovery, flare gas recovery and implementation of turbine inlet cooler. The result shows that the priority ranking for energy saving opportunities are placed on power plant set up,implementation of ISO 50001, energy performance assessment and monitoring regularly, flare gas recovery, waste heat recovery and implementation of turbine inlet cooler.
\end{abstract}

KEYWORDS: Energy audit, energy consumption, energy saving, priority

\section{Introduction}

Population increase and technology development has boosted consumption of energy, which contributes to economy, yet at the same time limits energy availability. This eventually improves people's awareness on sustainability matters and energy conservation as such.Conserving energy means preventing wasted energy in line with its original purpose to use energy efficiently[1].Today, Indonesia has been experiencing decrease of its energy reserve and increase of its energy consumption at the same time. Responding to that reality, the country in 2006 has declared an energy policy toattain energy elasticity valuelower than 1 by $2025[2\}$.

Indonesia energy conservation is initiatedthroughthe Presidential Instruction number 9/1982 regardingEnergy conservation as well as two other regulations that are: (a) Actnumber 30/2007 regardingEnergy and (b) Government Regulation number 70/2009 regardingEnergy conservation. Both are used as the basis to regulate energy utilization [3] such asarticle 12 of the second onestipulates that any partiesutilizing energy larger than 6,000 TOE annually are obliged to perform energy conservation through energy management system. This is stressed out by the publication of Ministry Decree number 14/2012 regarding Energy and Mineral Resources requiring implementation of energy management system. In industrial sectors including oil and gas, it is noted that in 2013, their consumptionhave reachedaround 399,688 MBOE [4]. The oil and gas industries, especially plant,consume large energytorun utilities, equipment, machineries, and others. With this intensive use and consumption, there must be an energy audit in order to ensure achievement of energy performance and associated energy management program [5].

Various internal and external factors have obviously affected company's focuses and or priorities of which an analysis tool is needed.. The process of determining priorities of the energy program based on energy audit requires analytical hierarchy process (AHP). 


\section{Literature Review}

Analytical Hierarchy Process

The Analytical Hierarchy Process is an analytical methodthrough pairwise comparisonsin which it relies on expert judgementto draw to priorities' scales. The comparisons use scale of absolute judgments that represent how much one element dominates to another with respect to a given attribute. These judgments may be inconsistent, therefore AHP processes function to measure the inconsistencies and subsequently improve the judgments. The derived priority scale is synthesized through multiplying them by the priority of their parent nodes and adding for all nodes [14].

There are organized steps to lead to a decision in generating priorities.This is undertaken by decomposing a decision into:

1. Define problem and determine types of knowledge to be sought;

2. Structure decision hierarchy from the top on the decision goal, objectives from a broad perspective through intermediate levels (criteria on which subsequent elements depend) to the lowest level (which usually is a set of the alternatives).

3. Construct a set of pairwise comparison matrices. Each element in an upper level is used to compare elements in the level immediately below with respect to it.

4. Use priorities obtained from the comparisons to weigh themin the level immediately below.

5. Do this for every element.

6. For each element in the level below, add its weighed values and obtain its overall or global priority.

7. Continue this process of weighing and adding until the final priorities of the alternatives in the bottom most level are obtained.

There are seven pillars of the analytical hierarchy process:

1. Ratio scales, proportionality and normalized ratio scales.

2. Reciprocal paired comparisons.

3 . The sensitivity of the principal right eigenvector.

4. Clustering and using pivots to extend the scale.

5. Synthesis to create a one dimensional ratio scale for representing the overall outcome.

6. Rank preservation and reversal.

7. Integrating group judgments [15]
Table1 Saaty Rating Value

\begin{tabular}{|c|c|c|}
\hline $\begin{array}{l}\text { Intensity of } \\
\text { Importance }\end{array}$ & Definition & Explanation \\
\hline 1 & $\begin{array}{r}\text { Equal } \\
\text { importance }\end{array}$ & $\begin{array}{c}\text { Two activities } \\
\text { contribute } \\
\text { equally to the } \\
\text { objective. }\end{array}$ \\
\hline 2 & $\begin{array}{l}\text { Weak or slight } \\
\text { importance }\end{array}$ & \\
\hline 3 & $\begin{array}{l}\text { Moderate } \\
\text { importance }\end{array}$ & $\begin{array}{l}\text { Experience and } \\
\text { judgment } \\
\text { slightly refer to } \\
\text { one activity } \\
\text { over another. }\end{array}$ \\
\hline 4 & Moderate plus & \\
\hline 5 & $\begin{array}{c}\text { Strong } \\
\text { importance }\end{array}$ & $\begin{array}{l}\text { Experience and } \\
\text { judgment } \\
\text { strongly refer } \\
\text { to one activity } \\
\text { over another. }\end{array}$ \\
\hline 6 & Strong plus & \\
\hline 7 & $\begin{array}{l}\text { Very strong or } \\
\text { demonstrated } \\
\text { importance }\end{array}$ & $\begin{array}{l}\text { An activity } \\
\text { refers very } \\
\text { strongly over } \\
\text { another; its } \\
\text { dominance } \\
\text { demonstrated } \\
\text { in practice. }\end{array}$ \\
\hline 8 & Very, very strong & \\
\hline 9 & $\begin{array}{c}\text { Extreme } \\
\text { importance }\end{array}$ & $\begin{array}{l}\text { The evidence } \\
\text { refer to one } \\
\text { activity over } \\
\text { another is of } \\
\text { the highest } \\
\text { possible order } \\
\text { to affirmation. }\end{array}$ \\
\hline $\begin{array}{c}\text { Reciprocals } \\
\text { of above }\end{array}$ & $\begin{array}{c}\text { If activity I has } \\
\text { one of the above } \\
\text { non zero } \\
\text { numbers } \\
\text { assigned to it } \\
\text { when compared } \\
\text { with activity } \mathrm{j} \text {, } \\
\text { then } \mathrm{j} \text { has the } \\
\text { reciprocal value } \\
\text { when compared } \\
\text { with } \mathrm{i}\end{array}$ & $\begin{array}{l}\text { A reasonable } \\
\text { assumption. }\end{array}$ \\
\hline
\end{tabular}

Relative importance from each factor on every matrix row can be claimed as normalized relative weight. The normalized relative weight is the relative weight value for each factor in every column, by compared each scale by numbers of column. Normalized principal eigenvector is identical y normalize every column in pairwise comparison matrix. It is the mean of weight value, which obtained from every factor at each of row. 
Main eigenvector is the ratio weight from each factor.

Collection of opinion between factors to the others is independent whilstthis can lead to inconsistent answers given by respondents. Nonetheless, too many inconsistenciesare unwanted by which an index of consistency must be calculated to know whether it is acceptable or not.

$$
\begin{aligned}
& \text { Consistency Index }=\frac{\lambda_{\text {maximum }}-n}{n-1} \\
& \quad \ldots \ldots \ldots \ldots \ldots \ldots \ldots \ldots \ldots \ldots \ldots \ldots \ldots \ldots \ldots \ldots \ldots \ldots \\
& \lambda_{\text {maximum }}=\text { Biggest eigenvector value from } \\
& \text { matrix. } \\
& n \quad=\text { Numbers of matrix order. }
\end{aligned}
$$

The biggest eigenvector obtained by adding up the result of column number and main eigenvector multiplication. If the consistency index is 0 meansa consistent matrix. Saaty stipulates an inconsistency limitas measured by a consistency ratio, which is defined as a ratio between the consistency index and random index. If the consistency ratio is less than $10 \%$, then it is acceptable.

$$
\text { Consistency Ratio }=\frac{\text { Consistency Index }}{\text { Ratio Index }}
$$

Table 2. Ratio Index

\begin{tabular}{|c|c|c|c|c|c|c|c|c|c|c|}
\hline $\mathrm{n}$ & 1 & 2 & 3 & 4 & 5 & 6 & 7 & 8 & 9 & 10 \\
\hline $\begin{array}{c}\text { Ratio } \\
\text { Index }\end{array}$ & 0 & 0 & 0.58 & 0.9 & 1.12 & 1.24 & 1.32 & 1.41 & 1.45 & 1.49 \\
\hline
\end{tabular}

\section{Research Method}

The analyses on energy savings opportunities to reduce wastes and improve efficiency through energy conservation concept is proposed from the audit energy report.The structure on the AHP analysis is built from Problem, Goal, Criteria, Subcriteria and Alternatives. After the structure created, it will be rechecked to assure its adequacy reflectionto the problem. Pairwise comparison, eigenvector and any submitted calculation and processesgeneratescriteria priority and recommendation rank.

Goal of the project is energy conservation on an oil and gas operation is pursued through a hierarchy structure. The hierarchy within the structure consists of 4 criteria and sub criteria as follows:Criterion 1 Energy savings assessment with sub criteria Energy consumption decline on certain period, Energy elasticity decline on certain period and Energy intensity decline percentage. Criterion 2Financial capability has subcriteria ofMinimum cost, Payback period and Optimize timetable.
Criterion 3 Environment sustainability has subcriteria ofMinimize environmental pollution, Renewable resources and Fuel reserve. Criterion 4Human resources is explained in the subcriteria ofManagement, Technical skill and Enforcement.

There are 6 alternatives to support the above hierarchy within the structure of AHP. These are energy performance assessment and regular monitoring, implementation of ISO 50001, power plant set up, waste heat recovery, flare gas recovery and implementation of turbine inlet cooler. This research is carried out incorporating a software for AHP i.e expert choice.

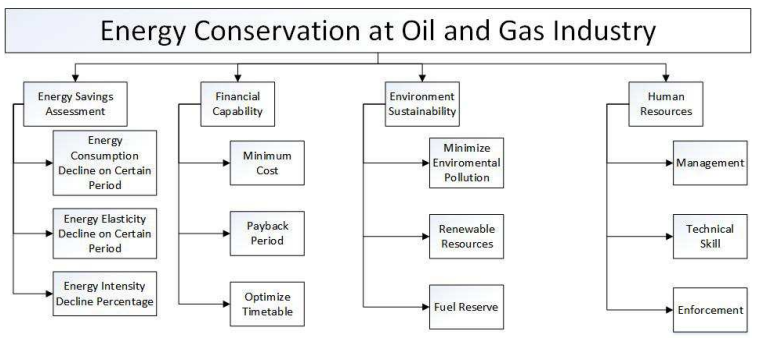

Figure 1 Hierarchy of Energy Conservation at Oil and Gas Industry

Figure 1 shows the four (4) criteria in which each criteria consists ofthree (3) sub criteria as elaborated in Table 3 . The process of selecting and deciding each criteria as well as sub criteria

\begin{tabular}{|c|c|c|}
\hline Criteria & Sub Criteria & Definition \\
\hline \multirow{3}{*}{$\begin{array}{c}\text { Energy } \\
\text { Savings } \\
\text { Assessment } \\
\text { (ESA) }\end{array}$} & $\begin{array}{c}\text { Energy } \\
\text { Consumption } \\
\text { Decline on } \\
\text { Certain Period } \\
\text { (ECDCP) } \\
\end{array}$ & $\begin{array}{l}\text { Energy consumption } \\
\text { declines regularly } \\
\text { within the time } \\
\text { measurement. }\end{array}$ \\
\hline & $\begin{array}{c}\text { Energy } \\
\text { Elasticity } \\
\text { Decline on } \\
\text { Certain Period } \\
\text { (EEDCP) } \\
\end{array}$ & $\begin{array}{lr}\text { Ratio of energy to } \\
\text { economic } & \text { growth } \\
\text { declines regularly } \\
\text { withinthe r time } \\
\text { measurement. }\end{array}$ \\
\hline & $\begin{array}{l}\text { Energy } \\
\text { Intensity } \\
\text { Decline } \\
\text { Percentage } \\
\text { (EIDP) }\end{array}$ & $\begin{array}{lr}\begin{array}{l}\text { Amount } \\
\text { energyneeded }\end{array} & \text { of } \\
\text { increase } & \text { gross } \\
\text { domestic product } \\
\text { declines regulary } \\
\text { within the time } \\
\text { measurement. }\end{array}$ \\
\hline \multirow[t]{2}{*}{$\begin{array}{l}\text { Financial } \\
\text { Capability } \\
\text { (FC) }\end{array}$} & $\begin{array}{l}\text { Minimum Cost } \\
\text { (MC) }\end{array}$ & $\begin{array}{l}\text { Energy conservation } \\
\text { is performedin } \\
\text { reduced cost both by } \\
\text { company and } \\
\text { government. }\end{array}$ \\
\hline & Payback Period & Return \\
\hline
\end{tabular}
refersto cases onenergy inefficiency and energy conservation provided by the Indonesian regulations.

Table 3 Criteria, Sub Criteria and Each Definition 


\begin{tabular}{|c|c|c|}
\hline & (PP) & $\begin{array}{l}\text { investment in the } \\
\text { period of time. }\end{array}$ \\
\hline & $\begin{array}{c}\text { Optimize } \\
\text { Timetable (OT) }\end{array}$ & $\begin{array}{l}\text { Optimize schedule } \\
\text { in one day to } \\
\text { minimize } \\
\text { expenditure }\end{array}$ \\
\hline \multirow{3}{*}{$\begin{array}{c}\text { Environment } \\
\text { Sustainability } \\
\text { (ES) }\end{array}$} & $\begin{array}{l}\text { Minimum } \\
\text { Environmental } \\
\text { Pollution } \\
\text { (MEP) }\end{array}$ & $\begin{array}{l}\text { Energy conservation } \\
\text { shall be undertaken } \\
\text { using } \\
\text { technologyproving } \\
\text { as energy efficient } \\
\text { equipments. }\end{array}$ \\
\hline & $\begin{array}{c}\text { Renewable } \\
\text { Resources (RR) }\end{array}$ & $\begin{array}{l}\text { Utilization of } \\
\text { efficient energy use } \\
\text { and due to the fossil } \\
\text { fuel occurs air } \\
\text { pollution, its reserve } \\
\text { depleting and others } \\
\text { harm impact. }\end{array}$ \\
\hline & $\begin{array}{ll}\text { Fuel } & \text { Reserve } \\
(\mathrm{FR}) & \end{array}$ & $\begin{array}{lr}\text { Fuel } & \text { reserve } \\
\text { according to the } \\
\text { Minister of Energy } \\
\text { and } \\
\text { Resources }\end{array}$ \\
\hline \multirow{3}{*}{$\begin{array}{l}\text { Human } \\
\text { Resources } \\
\text { (HR) }\end{array}$} & $\begin{array}{l}\text { Management } \\
\text { (M) }\end{array}$ & $\begin{array}{lr}\text { Coordination } & \text { to } \\
\text { accomplish } & \text { goals } \\
\text { effectively } & \text { and } \\
\text { efficiently. } & \end{array}$ \\
\hline & $\begin{array}{l}\text { Technical Skill } \\
\text { (TS) }\end{array}$ & $\begin{array}{lr}\text { Capability } & \text { to } \\
\text { perform } & \text { special } \\
\text { duty. } & \\
\end{array}$ \\
\hline & $\begin{array}{l}\text { Enforcement } \\
\text { (E) }\end{array}$ & $\begin{array}{l}\text { Consequent given to } \\
\text { not following } \\
\text { requirement }\end{array}$ \\
\hline
\end{tabular}

The four criteria have alternatives to be achieved through six (6) alternatives as the following: (1) Energy performance assessment and monitoring regularly (EPAMR). Regular monitoring and assessment to energy performance provides the company's management to close looks and make decision based on the data; (2) Implementation of ISO 50001 (50001), Secondly, an operation requires a management system to ensure consistency and assurance in improving the energy performance. (3) Power plant set up (PPSU); (4) Waste heat recovery (WHR); (5) Flue gas recovery (FGR); and (6) Implementation of turbine inlet cooler (ITIC)..

Whilst technological and engineering implementation through power plant set up, waste heat recovery, flue gas recovery and turbine inlet cooler will also contribute on the saving. With the same logic, the six alternatives affect the selection to other three sub criteria (financial capability, environmental sustainability and human resources). This argument is presented in Figure 2.

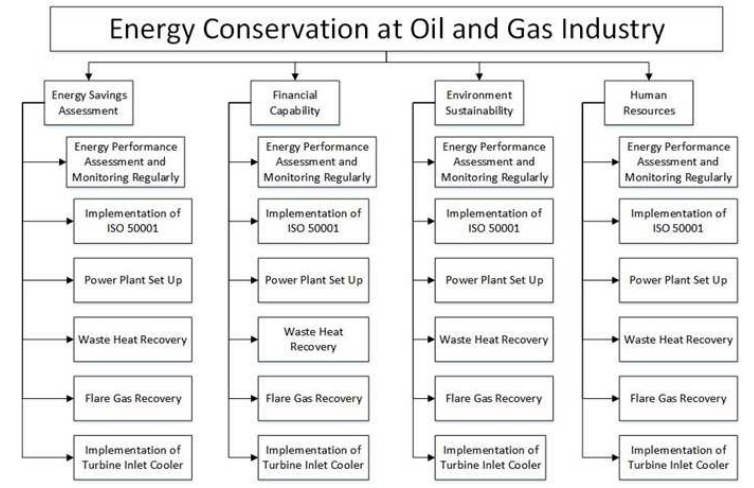

Figure 2. Criteria and Alternatives Hierarchy of Energy Conservation at Oil and Gas Industry

\section{IV.Result}

\subsection{Analytical Hierarchy Process}

\subsection{Criteria Pairwise Comparison}

After the hierarchy has been made, then pairwise comparison to criteria and sub criteria can be conducted.
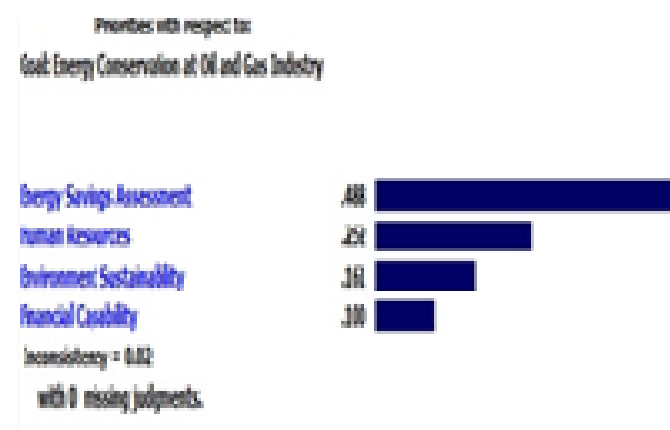

Figure 3. Result of Criteria Pairwise Comparison by Expert Choice

Figure 3 reveals that Energy savings assessment (ESA) takes $48.8 \%$ as the highest, followed by Human resources (HR)at $25.2 \%$, Environment sustainability (ES)at $16.1 \%$ and Financial capability (FC)at $10 \%$ to goal of energy conservation in an oil and gas industry. The reason ofthe energy savings assessmentdecided as the priority is that it is the easiest way to be carried out and the most representing operationalissues.Human resource is put on the second from the fact that conservation will be possible if there is personnel to execute it.The awareness on environmental protection has given criteria of environmental sustainability in the third reason to conserve energy and obviously financial capability is the last due to most understanding that energy conservation 
reduce financial performance of the company. The inconsistency ratio of the pairwise comparison is 0.02 or lower than 0.1 for which it is accepted.

$$
\begin{gathered}
\text { Consistency Ratio }=\frac{\text { Consigtency Index }}{\text { Ratio Index of } n=4} \\
=\frac{0.02}{0.9}=0.022=2.22 \%
\end{gathered}
$$

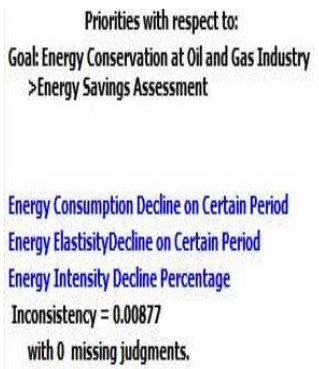

Figure 4. Result of Energy Savings Assessment Pairwise Comparison by Expert Choice

The decline on Energy consumption in certain period (ECICP)is considered to contribute directly on energy saving (ES) rather than the Decline on energy elasticity and energy intensity (....). Simply, the company operates in more efficient ways in using energy and minimizing wasted energy will conserve more. Although energy elasticity holds a more meaningful definition as energy consumption shall be correlated with volume of the related activities, yet this criteria is still considered lower to contribute than the first one. Similarly, the third criteria which the decline of the energy amount needed to increase gross domestic product on regular time measurement has not direct impact to energy conservation. The inconsistency ratio of the pairwise comparison is at 0.00877 or lower than 0.1 for which it is accepted.

$$
\begin{gathered}
\text { Consiatency Ratio }=\frac{\text { Consistency Index }}{\text { Ratio Index of } n=3} \\
=\frac{0.00877}{0.58}=0.0151=1.51 \%
\end{gathered}
$$

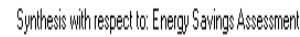

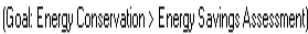
Oveall linconsistency $=07$

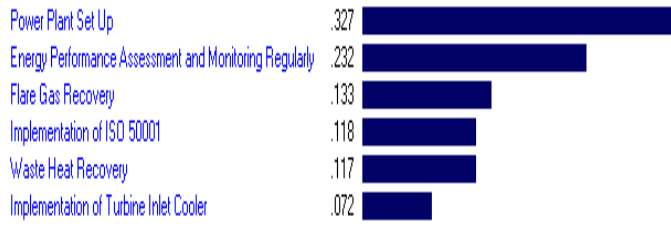

Figure 5. Synthesis from Energy Savings Assessment to Alternatives by Expert Choice
The question on alternative selected to enable energy saving assessment is answered in Figure 5 revealing that power plant set up as the first choice at $32.7 \%$. The reason is that it is the easiest condition to be assessed and the set up is able to reduce heat rate and increase system efficiency to significant number. Then, company shall monitor energy performance for which operational decisions can be made on the energy basis together with other operational factors such as revenue, productivity, safety and so forth. The second alternative reach at $23.2 \%$, although it is realized that this action is in fact does not really reduce wastes. Flare gas is visibly to show energy being released freely to environment of which it comes to the third alternative at $13.3 \%$, followed by energy management system ISO 50001 which is considered to be able to improve energy conservation through changes on management practices in utilizing energy rather than on applying technological change. This is at $11.8 \%$ which is very small different from the last alternative ofwaste heat recovery at $11.7 \%$.Figure 5 shows the inconsistency ratio of the pairwise comparison is 0.07 or lower than 0.1 for which it is accepted.

$$
\begin{gathered}
\text { Consistency Ratio }=\frac{\text { Congistency Index }}{\text { Ratio Index of } n=6} \\
=\frac{0.07}{1.24}=0.056=5.6 \%
\end{gathered}
$$

Priorities with respect to:

Goal: Energy Conservation at oil and Gas Industry

>Financial Capability

\section{Payback Period \\ Optimize Timetable \\ Minimum Cost \\ Inconsistency $=0.05$ \\ with 0 missing judgments.}

Figure 6. Result of Financial Capability Pairwise Comparison by Expert Choice

Any business decision relates to basic objective on getting back invested resources as soon as possible for which the payback period gives the highest selected option at $49.3 \%$. it is followed by the alternative to optimize the timetable at $31.1 \%$ with cause and effect reason that optimum management will conserve energy more than unorganized works. Interestingly, the minimum cost gains only at third option with a value of $19.6 \%$ which is quite distant with the second one. This could be understood by the fact that any energy conservation needs investment or cost to achieve instead of merely minimizing cost of operation and management. From the figure 6 its inconsistency ratio of the pairwise comparison is 0.05 or lower than 0.1 for which it is accepted. 


$$
\begin{gathered}
\text { Consistency Ratio }=\frac{\text { Consistency Index }}{\text { Ratio Index of } n=4} \\
=\frac{0.05}{0.9}=0.055=5.55 \%
\end{gathered}
$$

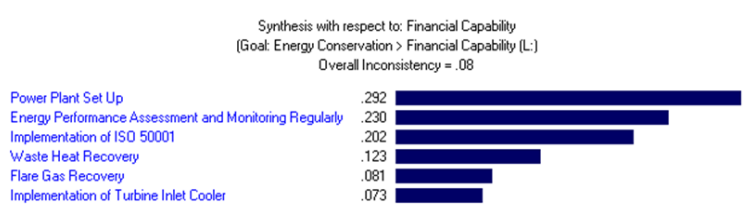

Figure 7. Synthesis from Financial Capability to Alternatives by Expert Choice

In achieving sub criteria of financial capability through payback period, optimum timetable and minimum cost, the highest decision is given to Power plant set up reaching a value of $29.2 \%$. This is comprehended from the fact that Power plant set up is expensive but it gives long time advantages and returns.A shutdown power plant mean loss of income although there is reduction onoperation cost. Then it is followedthe energy performance assessment and monitoring regularly, Implementation of ISO 50001 at the second and third option subsequently at a value of $23 \%$ and $20.2 \%$. Theenergy performance assessment and monitoring regularly is part of timetable and Implementation of ISO 50001 requires cheaper cost with a more assuring benefit. The last three options applies to Waste heat recovery (12.3\%), Flare gas recovery $(8.1 \%)$ and Implementation of turbine inlet cooler $(7.3 \%)$. The waste heat recovery and flare gas recovery whenever implementedneed longer years to revise than waste heat recovery and flare gas recovery maintenance. Finally, the implementation of turbine inlet cooler is considered costly resulted from its stuff price to training for the technician to be able to operate and maintain the system.

From the figure 4.49 the inconsistency ratio is 0.08 or it is lower than 0.1 for which it is accepted.

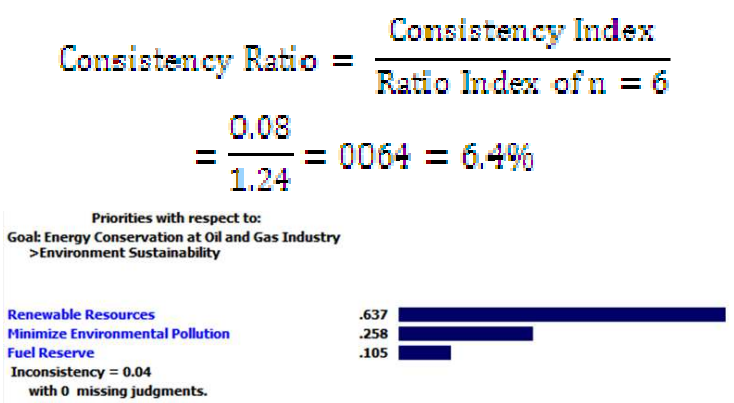

Figure 8. Result of Environment Sustainability Pairwise Comparison by Expert Choice
Similar to common knowledge that the best way to protect environment from energy utilization factors is by changing the energy source from non renewable resource (fossil fule and coal) to renewable one which in this reseach reach up to $63.7 \%$. Other reason is that availability of those non renewable is decreasing which endanger overall operation. This is in a distant different from the second option of Minimising environmental pollution at $25.8 \%$ since this is not a matter of releasing contaminated chemicals to environmental media instead of taking out from mother earth and feeding air with a $\mathrm{CO} 2$ blanket that causing temperature increase.The last option is to Fuel reserve at a value of $10.5 \%$. From the figure 8 . the inconsistency ratio is 0.04 or lower than 0.1 for which it is accepted.

$$
\begin{aligned}
\text { Consistency Ratio } & =\frac{\text { Consi stency Index }}{\text { Ratio Index of } \mathrm{n}=3} \\
=\frac{0.04}{0.58} & =0.068=6.8 \%
\end{aligned}
$$

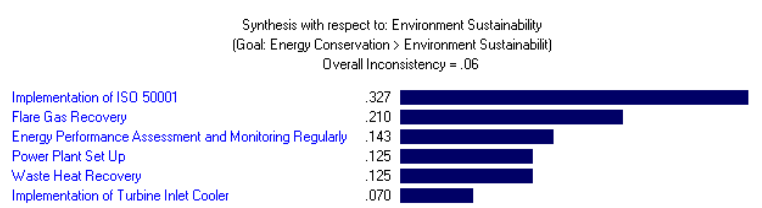

Figure 9. Synthesis from Environment

Sustainability to Alternatives by Expert Choice

In achieving goal of energy conservation through environmental sustainability criteria, the highest selection of alternatives lies on the Implementation of ISO 50001 at a value of $32.7 \%$ since energy management system is similar to environmental management system establish to protect environmental media. The second on Flare gas recovery reaches a value at $21 \%$ because the recovery obviously returning the impact to operation instead of releasing to air. The third is the Energy performance assessment and monitoring regularly (14.3\%) because of it, the company can monitor and control its environmental impacts. Power plant set up (12.5\%) is good if it relates to its contribution to Financial capability but it is not giving direct effect to environmental impact and so is the Flare gas recovery and Waste heat recovery. Implementation of turbine inlet cooler is 7\%, it less impact of pollution reduction and its main function is multiply the air volume that go in to the turbine. The figure 9 the inconsistency ratio is 0.06 or lower than 0.1 for which it is accepted.

$$
\begin{aligned}
& \text { Consistency Ratio }=\frac{\text { Congistency Index }}{\text { Ratio Index of } n=6} \\
& =\frac{0.06}{1.24}=0048=4.8 \%
\end{aligned}
$$


Priorities with respect to: Goal: Energy Conservation at oil and Gas Industry
$>$ Human Resources

Management
Technical Sk

Enforcement

consistency $=0.05$

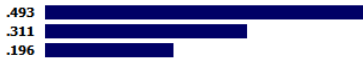

Figure 10. Result of Human Resources Pairwise Comparison by Expert Choice

Conserving energy can be applied to technological related matters and management things of which for a state of the art operation has design advantage to have most efficient operation and unit processes. Therefore the rest focus on the conservation places on the management changes relates to human resources. This is the reason that Management gains the highest option at $49.3 \%$. Technical skill has $31.1 \%$ for reasons that these high technology operation needs skillfull and knowledgeable technicians. Enforcement is $19.6 \%$, because connected to the maintain how to troubleshooting the problem and optimize timetable. From the figure 10 the inconsistency ratio is 0.05 .

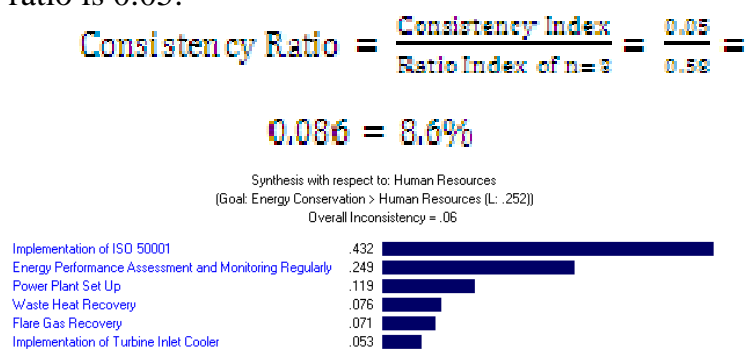

Figure 11.Synthesis from Human Resources to Alternatives by Expert Choice

A management system needs competent human resource to perform, on the way around human resource needs a management system in order to help standardization to achieve consistent and continual improvement. Therefore, Implementation of ISO 50001 is given quite high value at $43.2 \%$ considering the fact that both the advantage given by the system as mentioned before, the ISO 50001 addresses human resources clauses as requirements. Energy performance assessment and monitoring regularly has $24.9 \%$ because it connected to the timetable and regularly could develop the human resources. Power plant set up has $11.9 \%$ because it could develop human resources without addition training. Waste heat recovery has $7.6 \%$, flare gas recovery has $7.1 \%$ and implementation of turbine inlet cooler $5.3 \%$, those three has similarly low score because it needs new stuff and each training of them. From the figure 11 the inconsistency ratio is 0.06 .

$$
\begin{gathered}
\text { Consistency Ratio }=\frac{\text { Consistency Index }}{\text { Ratio Index of } n=6} \\
=\frac{0.06}{1.24}=0.048=4.8 \%
\end{gathered}
$$

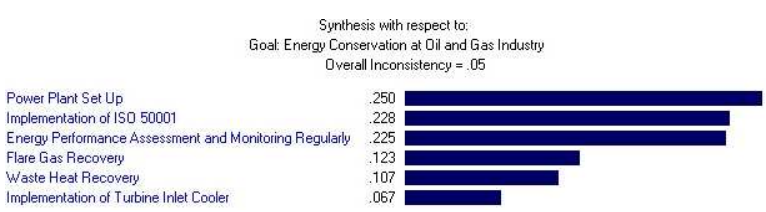

Figure 4.12 Priority of Alternative to The Main Goal

Figure 12 shows about connection of the goal and alternatives. Power plant set up takes $25 \%$, implementation of ISO 50001 is at $22.5 \%$, energy performance assessment and monitoring regularly is at $22.4 \%$, flare gas recovery is at $12.4 \%$, waste heat recovery is at $11 \%$ and implementation of turbine inlet cooler is at $6.8 \%$.

The first priority of the alternatives is given to Power plant set up because the least cost and its availability. Furthermore, the Power plant set up can reduce the heat rate and improve high number of efficiency of the system. Secondly, Implementation of ISO 50001 because it providesa management system to manage and as the foundation of systematic and sustainable performance. Thirdly, Energy performance assessment and monitoring regularly witha score slightly less than implementation of ISO 50001 due to interconnection between the two alternatives.Fourthly, Flare gas recovery is asits additional system, if being implemented, it needs more cost to buy, operate, maintain and train technicians although it reduce the emission in large numbers. Fiftly, Waste heat recovery is because it is also additional system, if it implemented, then it needs more cost to buy, operation, maintenance and training the technician although it reduce the emissions. The reason why waste heat recovery is less than flare gas recovery, because the system is more complicated and flare gas recovery reduce much more numbers in emission. Implementation of turbine inlet cooler is $6^{\text {th }}$ because the system is just to multiply the volume of gas that go into the turbine and makes it more efficient by that process.The inconsistency ratio of the pairwise comparison is 0.02 .

Consiatency Ratio $=\frac{\text { Consiatency Index }}{\text { Ratio Index of } n=6}=\frac{0.05}{1.24}=0.04=4 \%$

\section{Conclusion}

The selected option to save energy lies on the following order: Power plant set up, Implementation of ISO 50001, Energy performance assessment and monitoring, Flare gas recovery, Waste heat recovery, and Implementation of turbine inlet cooling. 


\section{References}

[1] JICA. 2005. JICA Thematic Guidelines on Energy Conservation. Japan International Cooperation Agency.

[2] Enerdata. 2011. Indonesia Energy Efficiency Report. United States of America: ABA Energy Corporation.

[3] So, Park Young. 2014. Implementasi Kebijakan Konservasi Energi di Indonesia. Bandung : Universitas Katolik Parahyangan.

[4] ESDM, Pusdatin. 2014. Handbook of Energy \& Economic Statistics of Indonesia. Jakarta: Ministry of Energy and Mineral Resources Republic of Indonesia.

[5] Hasanbeigi, Ali \& Price, Lynn. 2010. Industrial Energy Audit Guidebook: Guidelines for Conducting an Energy Audit in Industrial Facilities. United States of America: Berkeley National Laboratory.

[6] Ahmad S. et al. (2014). Selection of renewable energy sources for sustainable development of electricity generation system using analytic hierarchy process: A case of Malaysia. Renewable Energy, 63, 458. doi: http://dx.doi.org/10.1016/j.renene.20

\subsubsection{1}

[7] Chaudhury, A., Mandal, B. \& Das, S. (2015). Selection of appropriate fluid delivery technique for grinding titanium grade- 1 using the analytic hierarchy process. International Journal of Analytic Hierarchy Process, 7(3), 454-469.doi:

http://dx.doi.org/10.13033/ijahp.v7i3.356

[8] Dragincic, J. \& Vranesevic, M. (2014). AHPbased group decision making approach to supplier selection of irrigation equipment. International Journal of Water Resources Development: Economic and Legal Aspects, 41(6), 782-791. doi: $10.1134 /$ S0097807814060050

[9] Fallahpour, A., Olugu, E.U. \& Musa, S.N. (2015). A hybrid model for supplier selection: integration of AHP and multi expression programming (MEP). International Journal of Neural Computing and Application, 10, 1-6. URL:

link.springer.com/content/pdf/10.1007\%2Fs00 521-015-2078-6.pdf

[10] Mansor, M.R., Sapuna, S.M., Zainudin, E.S., Nuraini, A.A. \& Hambali, A. (2014). Application of integral AHP-TOPSIS method in hybrid natural fiber composites materials selection for automotive parking brake lever component. Australian Journal of Basic and Applied Sciences, 8(5), 431-439. URL:
www.ajbasweb.com/old/ajbas/2014/Special\%2 02/431-439.pdf

[11] Prabal Sapkota, Martina Pokharel, Madhav Prasad Pandey. (2016) Identifying the most suitable sustainable energy system for Nepal using Analytical Hierarchy Process, International Journal of The Analytical Hierarchy Process, 8 (2) URL://dx.doi.org/10.13033/ijahp.v8i2.411

[12] Nachtnebel, H.P. \& Singh, R.P.(2015). Prioritizing hydropower development using Analytical Hierarchy Process (AHP) - A case study of Nepal. International Journal of the Analytic Hierarchy Process, 7(2), 313-336. doi: http://dx.doi.org/10.13033/ijahp.v7i2.253

[13] Ankur Das, Santanu Das, (2016) Supplier for a Pump Manufacturing Organization by Hybrid AHP-Topsis Technique and Its Impact on Inventory, International Journal of the Analytic Hierarchy Process, 8(2), http://dx.doi.org/10.13033/ijahp.v8i2.380

[14] Saaty, Thomas L. 2008. Decision Making With The Analytical Hierarchy Process. United States of America: University of Pittsburgh.

[15] Saaty, T.L. \& Vargas, L.G. 2012. Models, Methods, Concepts \& Applications of the Analytic Hierarchy Process, DOI: 10.1007/9781-4614-3597-6_2. 